\title{
Toxicity of acrylamide and evaluation of its exposure in baby foods
}

\author{
Pınar Erkekoğlu and Terken Baydar* \\ Department of Toxicology, Faculty of Pharmacy, Hacettepe University, Ankara, Turkey
}

Contaminants are a vast subject area of food safety and quality and can be present in our food chain from raw materials to finished products. Acrylamide, an $\alpha, \beta$-unsaturated (conjugated) reactive molecule, can be detected as a contaminant in several foodstuffs including baby foods and infant formulas. It is anticipated that children will generally have intakes that are two to three times those of adults when expressed on a body-weight basis. Though exposure to acrylamide is inevitable, it is necessary to protect infant and children from high exposure. The present review focuses on the several adverse health effects of acrylamide including mutagenicity, genotoxicity, carcinogenicity, neurotoxicity and reproductive toxicity, and the possible outcomes of childhood exposure from baby foods and infant formulas.

\section{Acrylamide: Baby food: Infant formulas: Toxicity}

\section{Introduction}

Safe and adequate nutrition is crucial for the proper development of children. Other than breast milk, infant formulas and baby foods are the most important part of a baby's diet in the first year of life. Infant formulas, available in powder, liquid-concentrate and ready-to-feed forms, are artificial substitutes mimicking human breast milk. They are based on cows' milk or soya milk, designed for the consumption of infants. The medical community considers infant formulas as nutritionally acceptable for infants under the age of 1 year when breast-feeding is not possible. Infant formulas can be modified based on scientific evidence about the nutrient needs of infants ${ }^{(1,2)}$. Baby food is any food given to infants, with a soft, liquid texture, or that is chewed, from the age of 6 months to 2 years ${ }^{(2-4)}$. Baby foods are also consumed for 3 years as a part of the child's diet ${ }^{(1,2)}$. Baby foods include several baby purées made from fruits, vegetables or vegetables plus meat (beef, chicken or fish) sold commercially.

Formulation, handling and storage of baby foods are important for the foods' nutritional quality and physicochemical properties $^{(3)}$. There are several nutrients that an infant formula must contain according to the Food and Drug Administration through the advice of the American Academy of Pediatrics; it is also necessary to set upper limits for a nutrient in the formula ${ }^{(5,6)}$. On the other hand, infant formulas or baby foods can contain several contaminants that carry potential risk during the first years of life. A contaminant is an impurity; any material of an extraneous nature associated with a chemical, a pharmaceutical preparation, a physiological principle, or an infectious agent. Several contaminants, which can come from different stages of production and storage, may be present in infant formulas and baby foods. Food consumption is an important route of human exposure to contaminants such as acrylamide, pesticides and industrial pollutants ${ }^{(7,8)}$. As acrylamide is an anticipated contaminant of baby foods and infant formulas, and as children generally have acrylamide intakes that are two to three times those of adults when expressed on a body-weight (BW) basis, we will focus on acrylamide and its presence in baby foods and infant formulas in the present review ${ }^{(9)}$.

\section{Properties of acrylamide}

Acrylamide (acrylic amide; International Union of Pure and Applied Chemistry (IUPAC) name 2-propenamide), an $\alpha, \beta$ unsaturated (conjugated) reactive molecule, has the chemical formula $\mathrm{C}_{3} \mathrm{H}_{5} \mathrm{NO}^{(10,11)}$. It has a high mobility in soil and groundwater and is biodegradable ${ }^{(12)}$. It is also used in industry to manufacture polyacrylamide or its copolymers $^{(12,13)}$.

Acrylamide is inadvertently found in starchy foods such as crisps, chips and bread ${ }^{(14)}$. Its discovery in heated foods has received a high level of attention from the public and the medical community. Acrylamide in fried and baked foods is produced by the reaction between asparagines and reducing sugars (fructose, glucose) or reactive carbonyls ${ }^{(15,16)}$. Coffee drinking and smoking are other major sources apart from the human diet ${ }^{(17,18)}$. Boiling does not produce acrylamide, but baking, frying, deep-frying, over-cooking and microwaving produce large amounts of acrylamide in

Abbreviations: BW, body weight; GSH, glutathione; NOAEL, no observed adverse effect level.

* Corresponding author: Dr Terken Baydar, email tbaydar@hacettepe.edu.tr 
foodstuffs ${ }^{(14)}$. On the other hand, water is one of the major sources of exposure, as polyacrylamide is used mainly for the purification of drinking water as a flocculating agent $^{(12,13)}$.

Acrylamide is classified as 'probably carcinogenic to humans (group 2A)' by the International Agency for Research on Cancer. There is inadequate evidence in humans for the carcinogenicity of acrylamide ${ }^{(10)}$.

\section{Biotransformation of acrylamide}

\section{Absorption}

According to data derived from animal studies, acrylamide is quickly absorbed by the skin and by the mucosa if inhaled. If taken by the oral route, it can diffuse evenly in the body because of its hydrosolubility ${ }^{(11)}$.

\section{Distribution}

Tissue distribution is not significantly affected by dose or route of administration. The highest concentrations are found in erythrocytes. Despite the prominence of neurological effects, acrylamide is not concentrated in nervous system tissues ${ }^{(19)}$. Acrylamide readily crosses the placenta $^{(20)}$.

\section{Metabolism}

In blood, acrylamide has a half-life of approximately $2 \mathrm{~h}$. In tissues, total acrylamide (parent compound and metabolites) exhibits biphasic elimination with an initial half-life of approximately $5 \mathrm{~h}$ and a terminal half-life of $8 \mathrm{~d}$. Acrylamide does not accumulate in the body ${ }^{(14,20,21)}$.
At low doses $50 \%$ of acrylamide is oxidised to a DNAreactive epoxide, glycidamide, by cytochrome 2E1 (CYP2E1). CYP2E1 polymorphisms in mice can cause different amounts of glycidamide to be formed. Wild-type mice have been found to metabolise $50 \%$ of the administered dose of acrylamide to glycidamide; however, CYP2E1-null mice could not metabolise acrylamide to glycidamide ${ }^{(22)}$. Glycidamide can be metabolised by epoxide hydrolase or can undergo conjugation with glutathione $(\mathrm{GSH})^{(12,21,23-25)}$.

\section{Excretion}

The major pathway of metabolism for acrylamide is its conjugation with reduced GSH by glutathione $S$-transferase. Conditions such as malnutrition, oxidative stress and liver disease (alcoholic hepatitis, cirrhosis, and other malignant liver disorders) can decrease the GSH content of liver. Since a child's liver cannot carry as high a burden as an adult liver, especially under such conditions, a higher toxicity of acrylamide might be anticipated in children. Elimination occurs mainly in the urine as mercapturic acid conjugates. Greater than $90 \%$ of absorbed acrylamide is excreted in the urine as metabolites. Less than $2 \%$ is excreted as unchanged acrylamide. Smaller amounts are excreted in the bile and faeces. Approximately $60 \%$ of an administered dose appears in the urine within $24 \mathrm{~h}^{(14)}$. Biotransformation of acrylamide is summarised in Fig. 1.

\section{Toxicity of acrylamide}

There are several health risks caused by the intake of acrylamide from several routes. Smoking by the mother is a major way by which the neonate is exposed to

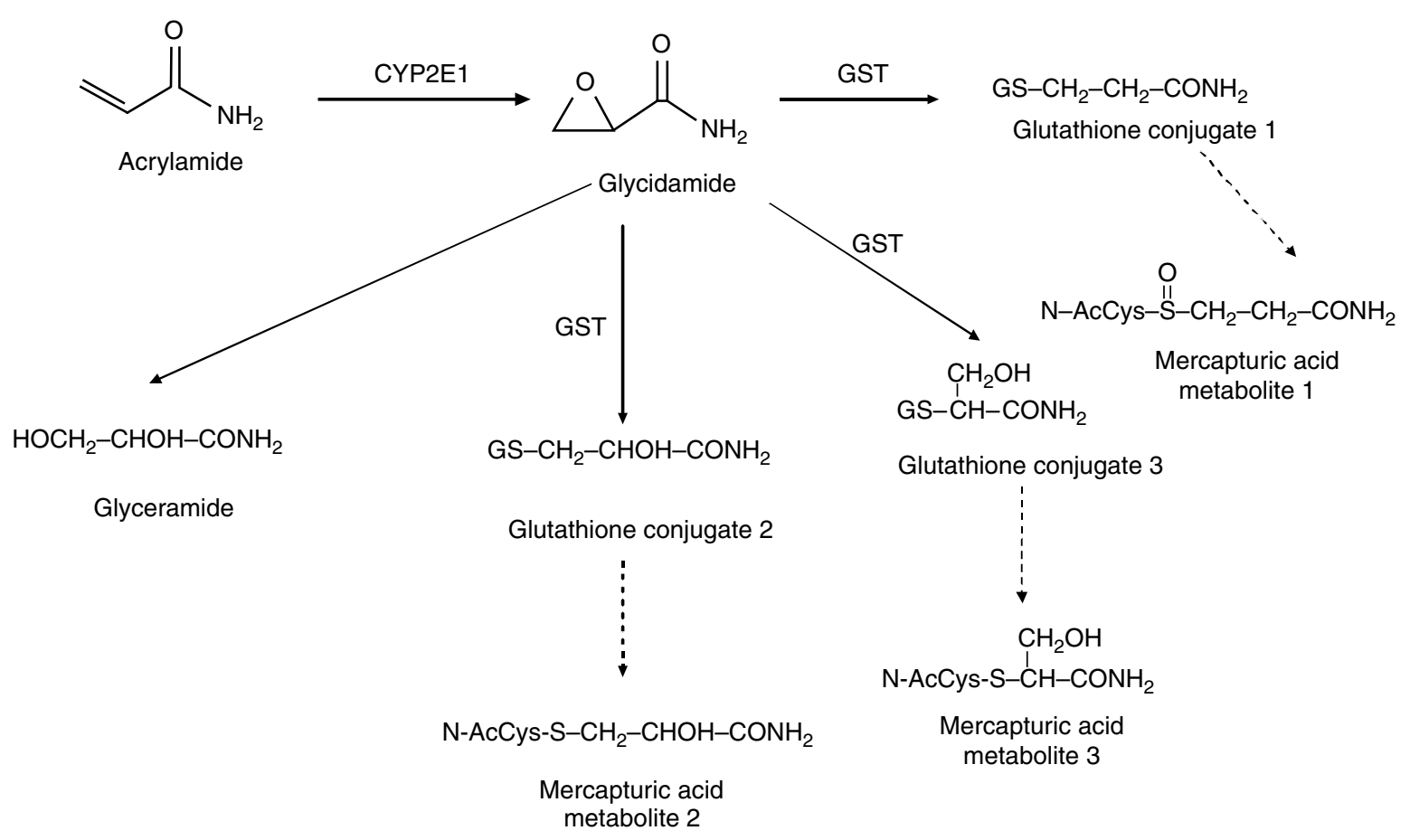

Fig. 1. Biotransformation mechanism of acrylamide. CYP2E1, cytochrome 2E1; GST, glutathione S-transferase. 
acrylamide $^{(26)}$. In addition, contaminated foodstuffs and drinking water are two other main ways to expose the baby or child to acrylamide. As children, especially those under the age of 2 years, are the most sensitive population, acrylamide intake levels must be monitored particularly in infant formulas and baby foods. On the other hand, mothers should be attentive while choosing the water with which they prepare food for their child. The health risks of acrylamide can be classified as follows.

\section{Mutagenic, genotoxic and carcinogenic properties of acrylamide}

The genotoxic, mutagenic and carcinogenic potentials of acrylamide have been studied extensively. Acrylamide itself reacts rapidly with thiol $(-\mathrm{SH})$ and amino groups; this explains why its primary targets are proteins ${ }^{(25)}$. Acrylamide has been shown to bind DNA by a Michael-type process in vitro with low activity ${ }^{(21,25)}$. Nevertheless, there is sufficient evidence in the literature that both acrylamide and its metabolite glycidamide are mutagenic and clastogenic in mammalian cells ${ }^{(19,22)}$. Data suggest that mice are more vulnerable to acrylamide tumorigenicity. The metabolic activation of acrylamide is more efficient and the detoxification process is poorer in mice than rats, since mice have higher levels of glycidamide and lower levels of GSH-glycidamide conjugates ${ }^{(27)}$.

Acrylamide causes induction of the following genotoxic effects $^{(28,29)}$.

(a) gene mutations and chromosomal aberrations in germ cells of mice in vivo;

(b) chromosomal aberrations in germ cells of rats in vivo;

(c) chromosomal aberrations in somatic cells of rodents in vivo;

(d) gene mutations and chromosomal aberrations in cultured cells in vitro;

(e) cell transformation in mouse cell lines;

(f) somatic mutation in the spot test in vivo;

(g) heritable translocation and specific locus mutations in mice and dominant lethal mutations in both mice and rats;

(h) unscheduled DNA synthesis in rat spermatocytes in vivo; but not in rat hepatocytes. However, glycidamide induces unscheduled DNA synthesis in rat hepatocytes.

The studies on mutagenic, genotoxic and carcinogenic properties of acrylamide and glycidamide are summarised in Table $1^{(29-43)}$.

\section{Adduct formation with $\mathrm{Hb}$}

Acrylamide forms different protein adducts, the most important of which are $\mathrm{Hb}$ adducts extensively formed at - SH groups and on the amino groups of the N-terminal valines in erythrocytes. The measurement of $\mathrm{Hb}$ adducts can give an integrated measure of the exposure in the previous 3-4 months, since the lifespan of erythrocytes is about 4 months ${ }^{(25,44)}$.

Adduct formation with acrylamide shows a linear doseresponse relationship and glycidamide adducts generate a concave curve. This shows that the percentage of acrylamide metabolised to glycidamide is inversely proportional to the administered dose of acrylamide ${ }^{(45,46)}$.

\section{Neurotoxic effects of acrylamide}

Early morphological studies suggested that neurological defects caused by acrylamide intoxication are mediated through distal axonal degeneration (also known as 'dyingback' neuropathy) in the peripheral nervous system and central peripheral nervous system ${ }^{(47,48)}$. Later studies showed that nerve terminals and Purkinje neurons are the targets of acrylamide ${ }^{(49)}$. Nowadays, there are two important hypotheses regarding acrylamide neurotoxicity: (a) inhibition of kinesin-based fast axonal transport; (b) direct inhibition of neurotransmission ${ }^{(50,51)}$.

Acrylamide, the parent compound, is a soft electrophilic neurotoxicant, reacting on thiol groups of proteins (cysteine, homocysteine) and GSH as well as protein-bound - $\mathrm{SH}$ groups (kinesin, dynein), whereas the metabolite glycidamide is a harder electrophilic compound, reacting with nucleophilic centres of adenine and guanine in the DNA $^{(37-41)}$. It has been shown that acrylamide inhibits the action of brain glutathione $S$-transferase and reduces the levels of brain $\mathrm{GSH}^{(52)}$. It has also been suggested that acrylamide neurotoxicity is caused by its effects on heavyand medium-weight neurofilaments, the change it causes on neurotransmitter receptor expression and through inhibition of neurotransmission ${ }^{(43-45)}$. Electrophilic neurotoxins, including acrylamide, may cause protein structure and function changes by oxidation and this may lead to pathway failure and finally nerve cell damage. Therefore such chemicals at low doses and long-term exposure might be a cause of neurodegenerative diseases such as Alzheimer's disease ${ }^{(12,35,53,54)}$. The studies on neurotoxic effects of acrylamide and glycidamide are summarised in Table $1^{(29,35,55-57)}$.

\section{Reproductive and developmental toxicity of acrylamide}

Reproductive toxicity has also been observed in laboratory animals exposed to high levels of acrylamide ${ }^{(55)}$. Several studies have been conducted on reproductive toxicity; these are presented in Table $1^{(58-62)}$.

There seems to be a relationship between the neurotoxicity and reproductive toxicity of acrylamide ${ }^{(56,62-65)}$. One theory is that reproductive toxicity is related to neurotoxicity, as neurotoxicity influences mating behaviour. Several studies have clarified that some of the neurotoxic effects of acrylamide in rats are a weakness of the hind-limbs, reduced hind-limb grip strength, and increased foot splay ${ }^{(62,63,65)}$. This reduced hind-limb function could cause impairment in mounting responses, copulatory behaviour, and intromission $(\text { entry })^{(58)}$. Dysfunctional intromission could also have an impact on the proper deposition of sperm in the vagina and uterus and subsequent hormonal events that cause the stimulation of reproductive hormones and implantation. In addition, erectile function could be decreased due to nerve damage in the penis ${ }^{(66)}$. Another theory is that both types of toxicity are mediated through effects on the kinesin motor proteins ${ }^{(62)}$. These kinesin proteins are found in the flagella of sperm as well as the nervous system and other tissues ${ }^{(65)}$. 


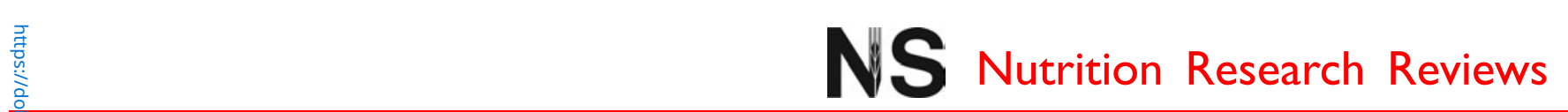

Table 1. Summary of literature on mutagenicity, genotoxicity, carcinogenicity, neurotoxicity, reproductive and developmental toxicity of acrylamide

\begin{tabular}{|c|c|}
\hline Study & Study design \\
\hline \multicolumn{2}{|c|}{ Mutagenic, genotoxic and carcinogenic properties of acrylamide } \\
\hline $\begin{array}{l}\text { Hashimoto \& Tanii } \\
\quad(1985)^{(29)}\end{array}$ & $\begin{array}{l}\text { Mutagenicity testing of acrylamide and glycidamide on Salmonella } \\
\text { strains }\end{array}$ \\
\hline $\begin{array}{l}\text { National Toxicology } \\
\text { Program (1989) }\end{array}$ & $\begin{array}{l}\text { Acrylamide was administered to } \mathrm{F} 344 / \mathrm{N} \text { rats and } \mathrm{B} 6 \mathrm{C} 3 \mathrm{~F} 1 \text { mice by } \\
\text { oral administration }\end{array}$ \\
\hline Russell et al. (1991) & Induction of specific-locus mutations in male germ cells of the mouse \\
\hline Hoorn et al. $(1993)^{(32)}$ & $\begin{array}{l}\text { A transgenic mouse strain with a high copy number of rescuable lac } Z \\
\text { sequences was evaluated for its effectiveness in detecting lac } Z \\
\text { mutations }\end{array}$ \\
\hline Dearfield et al. (1995) ${ }^{(33)}$ & $\begin{array}{l}\text { Hypoxanthine-guanine phosphoribosyl transferase locus in cultured } \\
\mathrm{CHO} \text { cells }\end{array}$ \\
\hline $\begin{array}{l}\text { Segerbäck et al. } \\
(1995)^{(34)}\end{array}$ & $\begin{array}{l}\text { Testing DNA damage potential of acrylamide and glycidamide on rats } \\
\text { and mice }\end{array}$ \\
\hline Fu et al. $(2000)^{(35)}$ & Neonatal mouse tumorigenicity bioassay \\
\hline $\begin{array}{l}\text { Gamboa de Costa et al. } \\
(2003)^{(36)}\end{array}$ & $\begin{array}{l}\text { Induction of DNA adduct formation of acrylamide and glycidamide in } \\
\text { adult and neonatal mice }\end{array}$ \\
\hline Ma et al. $(2008)^{(37)}$ & $\begin{array}{l}\text { Comet assay on lung, liver, spleen, kidney, testicle, bone marrow and } \\
\text { peripheral lymphocytes of mice }\end{array}$ \\
\hline Cao et al. $(2008)^{(38)}$ & Comet assay on HepG2 cells \\
\hline Zhang et al. (2008) $)^{(39)}$ & Micronucleus assay on HepG2 cells \\
\hline Baum et al. (2008) & Comet assay on V79 cells and in human lymphocytes \\
\hline Wolf et al. (2008) ${ }^{(41)}$ & Micronucleus assay on hens' eggs \\
\hline Recio et al. $(2010)^{(42)}$ & Micronucleus/comet assays on rats and mice \\
\hline Mei et al. $(2010)^{(43)}$ & Micronucleus and $H p r t$ assays on rats \\
\hline
\end{tabular}

Neurotoxic effects of acrylamide

Burek et al. (1980) $)^{(55)}$
Male and female Fischer 344 rats were administered acrylamide in their drinking water at $0,0.05,0.2,1,5$, or $20 \mathrm{mg} / \mathrm{kg}$ per $\mathrm{d}$ for up to $93 \mathrm{~d}$. Following the administration of acrylamide in the drinking water, male rats from each dose level were held for up to $144 \mathrm{~d}$ of recovery
Acrylamide was not mutagenic in Ames' test, in the presence of the S9 fraction; however, glycidamide was shown to be mutagenic in some of the fraction; however, glycidamide was shown to be muth
strains of Salmonella, with or without the S9 mix

strains of Salmonella, with or without the S9 mix
Acrylamide showed organ-specific and species-specific tumorigenicity in rodents. Application of acrylamide through different routes (topically, orally, systemically) increased the risk of carcinomas and lung and skin adenomas in mice and induced thyroid adenomas/adenocarcinomas, uterine adenocarcinomas, clitoral adenomas, oral papillomas and mammary gland tumours in rats

Significantly increased the specific-locus mutation rate in certain poststem-cell stages of spermatogenesis, but not in spermatogonial stem cells Acrylamide was found to increase the frequency of lac $Z$ mutations in bone marrow about 1.8-fold over background

Acrylamide has shown to be mutagenic at the hypoxanthine-guanine phosphoribosyl transferase locus in cultured $\mathrm{CHO}$ cells with or without exogenous activation system

Glycidamide was found to induce N-7-(2-carbamoyl-2-hydroxy-ethyl)gua-

nine
Glycidamide showed 5- to 7-fold higher DNA adduct levels than when treated with acrylamide, indicating lower levels of CYP450 enzymes in immature tissues

Both acrylamide and glycidamide caused DNA adduct formation; however, adduct levels formed by glycidamide were modestly higher

Acrylamide caused DNA damage to multiple organs of mice

Acrylamide caused DNA damage

Acrylamide increased micronucleus frequencies

Glycidamide caused DNA damage

Acrylamide increased micronucleus frequencies

Acrylamide was found to induce micronucleated reticulocytes in rats

Neither acrylamide nor glycidamide increased the frequency of micronucleated reticulocytes. In contrast, both compounds produced small (approximately 2- to 3-fold above background) but significant increases in lymphocyte Hprt mutant frequency

Nerve degeneration was observed; however, after $144 \mathrm{~d}$, the lesions were partially or fully recovered 
Chapin et al. (1995) ${ }^{(56)}$

\section{Ghanayem et al.} $(2010)^{(57)}$

Reproductive toxicity of acrylamide

Zenick et al. $(1986)^{(58)}$

Sublet et al. (1989) $)^{(59)}$

Wise et al. $(1995)^{(60)}$

Field et al. (1990) ${ }^{(61)}$

Tyl et al. (2000) ${ }^{(62)}$
Male and female Swiss CD-1 mice received acrylamide in drinking water $(3,10,30 \mathrm{ppm})$ for 14 weeks

Neurotoxicity was assessed at several times in both F0 and F1

generations by measuring forelimb and hindlimb grip strength

\section{5- to 30-week-old intact male $\mathrm{C} 57 \mathrm{BI} / 6 \mathrm{~J}$ mice fed with low- and} high-energy diets

Male rats received acrylamide in drinking water $(50,100$, or $200 \mathrm{ppm})$ for up to 10 weeks. Copulatory behaviour, semen, and (for controls and $100 \mathrm{ppm}$ only) fertility and fetal outcomes were evaluated. Females received acrylamide $(25,50,100 \mathrm{ppm})$ for 2 weeks before initiation of breeding and then throughout gestation and lactation

Males were orally administered with $0,5,15,30,45$, or $60 \mathrm{mg} / \mathrm{kg}$ acrylamide for $5 \mathrm{~d}$ and then mated serially to naive females

Acrylamide at $0,5,10,15$, or $20 \mathrm{mg} / \mathrm{kg}$ per d were administered at $5 \mathrm{ml} / \mathrm{kg}$ by oral administration from GD 6 to lactational day 10 to groups of twelve mated females each

Sprague-Dawley rats received acrylamide at $0,2.5,7.5$, and $15 \mathrm{mg} / \mathrm{kg}$ body weight per d on GD $6-20$. Swiss $C D-1$ mice received acrylamide at $0,3,15$, and $45 \mathrm{mg} / \mathrm{kg}$ body weight per d on GD $6-17$

160 Male, 160 female virgin rats; $0,5,15,30,45$, or $60 \mathrm{mg} / \mathrm{kg}$ per $\mathrm{d}$ for $5 \mathrm{~d}$
Presence of only minor effects on grip strength and without detectable neural histopathology. Female reproduction was not significantly affected by these compounds at the doses used. Thus, these data confirm the male as the affected sex and that reproductive toxicity was greater than motor neuron toxicity when measured as grip strength

In the F0 generation, acrylamide caused an $11 \%$ decrease in pup number without measurable neurotoxicity; female fertility was not affected. Although both generations consumed the same amount of acrylamide, there were larger changes in the fertility-related endpoints in the F1 mice than in the FO mice, with no concomitant change in organ weights or sperm parameters

Acrylamide potentiated the repoductive toxicity induced by obesity in obese rats

Disruptions in mating performance, a decrease in pregnancy rate, an increase in post-implantation loss, and hindlimb splaying appeared in the females; a decrease in pup body weight at birth, decreases in weight gain during lactation, and a delay in vaginal patency were also observed

Acrylamide treatment reduced fertility and increased pre- and postimplantation loss, primarily over the first 3 weeks post-treatment However, the effects were transient

Significantly increased pup mortality and characteristic hindlimb splaying; significant decreases in average horizontal motor activity and auditory startle response were observed only in weanlings of the $15 \mathrm{mg} / \mathrm{kg}$ per group

Maternal and fetal weight decreases and extra rips were observed in a dosedependent manner

At 15 to $60 \mathrm{mg} / \mathrm{kg}$ per $\mathrm{d}$, males exhibited significantly reduced weight gain and reduced mating. Females showed a decrease in pregnancy rate. Also, increased post-implantation losses were observed at the $60 \mathrm{mg} / \mathrm{kg}$ per d dose

CHO, Chinese hamster ovary; CYP450, cytochrome 450; ppm, parts per million; GD, gestation day. 
Interference with these proteins could reduce sperm motility and fertilisation events ${ }^{(62,66,67-70)}$.

Other mechanisms of acrylamide on reproduction in rodents could be from the alkylation of sulfhydryl groups on unique proteins, such as protamine, in the sperm head and tail $^{(22,71,72)}$. This could affect sperm penetration and induce the pre-implantation losses seen in some dominant lethal studies $^{(62,73)}$.

No human data are present regarding the reproductive and developmental toxicity of acrylamide. However, data are sufficient to conclude that acrylamide is a reproductive and developmental toxicant in rodents.

\section{Dose-response and dose-effect relationships of acrylamide}

Numerous investigators have looked at dose-response and dose-effect relationships in a variety of animal models. There do not appear to be significant differences between the mammalian species studied. The lethal dose, $50 \%$ $\left(\mathrm{LD}_{50}\right)$ levels of acrylamide through various routes in different rodents are given in Table $2^{(74)}$.

The WHO states that acrylamide belongs to the group of chemicals thought to have no reliably identifiable 'threshold' of effects, meaning that very low concentrations will also result in very low risks, but not in zero risk: some risk is always present when the chemical is ingested. However, for carcinogens such as acrylamide, risk is thought to increase with increasing exposure ${ }^{(75)}$.

In June 2002, the FAO of the UN and the WHO issued a report about the health implications of acrylamide in food. The Consultation concluded that the no observed adverse effect level (NOAEL) for acrylamide neuropathy is $0.5 \mathrm{mg} / \mathrm{kg} \mathrm{BW}$ per $\mathrm{d}$ and the NOAEL for fertility changes is four times higher than for peripheral neuropathy and 2000 -fold greater than estimated dietary exposures $(24,76,77)$. The NOAEL for reproductive toxicity was estimated to be $2-5 \mathrm{mg} / \mathrm{kg}$ BW per d depending on the endpoint of fertility or embryonic death ${ }^{(77)}$. No reproductive toxicities have been reported in humans. Therefore, it is highly unlikely that any reproductive toxicity in humans would result from dietary exposure to acrylamide, although concerns about the cumulative effects of low-level chronic exposure are increasing.

Evidence of neurological effects has been observed following single oral doses of $126 \mathrm{mg} / \mathrm{kg}$ in rats and rabbits and $100 \mathrm{mg} / \mathrm{kg}$ in $\operatorname{dogs}^{(78,79)}$. Using chronic dosing schedules, it has been observed that cumulative oral doses of $500-600 \mathrm{mg} / \mathrm{kg}$ using daily doses of $25-50 \mathrm{mg} / \mathrm{kg}$ per d are required to produce ataxia in rats, $\operatorname{dogs}$ and

Table 2. Lethal dose, $50 \%\left(L_{50}\right)$ levels of acrylamide through different routes in different rodents

\begin{tabular}{|c|c|c|}
\hline Species & Route & $\begin{array}{c}\mathrm{LD}_{50} \\
\text { (mg/kg body weight) }\end{array}$ \\
\hline Rat & Oral & $107-251$ \\
\hline Rat & Dermal & 400 \\
\hline Rat & Intraperitoneal & $90-120$ \\
\hline Mouse & Oral & $107-170$ \\
\hline Guinea-pig & Oral & $150-180$ \\
\hline
\end{tabular}

baboons ${ }^{(78,80,81)}$. Smaller daily doses do not produce a clinical effect until a larger cumulative dose is attained. It has been found that the administration of acrylamide at daily doses of 6 to $9 \mathrm{mg} / \mathrm{kg}$ does not produce evidence of neurotoxicity in rats until a cumulative dose of 1200 to $1800 \mathrm{mg} / \mathrm{kg}$ is attained, and that doses of up to $3 \mathrm{mg} / \mathrm{kg}$ per d for $90 \mathrm{~d}$ administered to rats do not result in adverse effects ${ }^{(78,82)}$. Spencer et al. ${ }^{(83)}$ reported that Rhesus monkeys fed up to $2 \mathrm{mg} / \mathrm{kg}$ per d did not show any adverse clinical effects at $325 \mathrm{~d}$.

Acrylamide appears to be a multi-organ carcinogen in rodents. This is consistent with its distribution throughout the whole body. However, it is noteworthy that there are no corresponding target organs in mice and rats. Rat thyroid follicular cell tumours and mammary tumours from two studies are considered of possible relevance for human health. Modelling of these data has allowed the determination of benchmark doses and benchmark dose lower confidence limits ${ }^{(84,85)}$. For a $10 \% \mathrm{CI}$, the results were in the range of $300-1100 \mu \mathrm{g} / \mathrm{kg}$ per $\mathrm{d}$ for the mammary tumours and between 630 and 930 for the thyroid tumours using the Environmental Protection Agency's dose-response modelling for determination of a point of departure for a risk of $10 \%$ lower exposure dose $\left(\operatorname{LED}_{10}\right)^{86,87)}$. Relating the combined tumour data to $\mathrm{Hb}$ adduct data of acrylamide and glycidamide the doses 440 or $950 \mu \mathrm{g} / \mathrm{kg}$ per $\mathrm{d}$ were determined, respectively, which are close to the benchmark dose lower confidence limits ${ }^{(86-88)}$.

The estimated average chronic human dietary intake was calculated crudely as $0 \cdot 3-0.7 \mu \mathrm{g} / \mathrm{kg}$ BW per d in 2002. However, the Food and Drug Administration calculated the exact intake as $0.4 \mu \mathrm{g} / \mathrm{kg} \mathrm{BW}$ per $\mathrm{d}$ in 2003 and this value remained the same when the Food and Drug Administration updated this subject in $2004^{(89)}$. This increase of acrylamide intake by age seems to reflect the increased consumption of fast food together with potato crisps or French fries.

As the NOAEL for neuropathy is given as $0.5 \mathrm{mg} / \mathrm{kg} \mathrm{BW}$ per $\mathrm{d}$, a woman weighing $132 \mathrm{lb}(60 \mathrm{~kg})$ could safely consume $30 \mathrm{mg}$ acrylamide daily; a man weighing $180 \mathrm{lb}$ $(82 \mathrm{~kg})$ could consume about $41 \mathrm{mg}^{(90)}$. On the other hand, if the same calculation is applied to the daily intake of a child, a child weighing $20 \mathrm{lb}(9 \mathrm{~kg})$ can consume food including $4.5 \mathrm{mg}$ acrylamide. Whether it is appropriate to judge the daily intake of a child with the same calculation is a matter of debate considering that the susceptibility of a child towards several chemicals is much higher than that of an adult. It is anticipated that children will generally have intakes that are two to three times those of adults when expressed on a BW basis.

Studies on acrylamide contamination in baby foods and infant formulas and estimated daily exposures of acrylamide are given in Table $3^{(26,91-94)}$.

\section{Determination of acrylamide and limits in foods}

Potentially toxic acrylamide is largely derived from heatinduced reactions between the amino group of the free amino acid asparagine and carbonyl groups of glucose and fructose in cereals, potatoes, and other plant-derived foods ${ }^{(95)}$. Several methods have been described that determine acrylamide in several foodstuffs and water. 
Table 3. The daily intake of acrylamide of children in several European countries

\begin{tabular}{|c|c|c|c|}
\hline Study & Data & Age & $\begin{array}{l}\text { Acrylamide intake } \\
(\mu \mathrm{g} / \mathrm{kg} \mathrm{BW} \text { per } \mathrm{d})\end{array}$ \\
\hline \multirow{3}{*}{$\begin{array}{l}\text { Alexy et al. (DONALD Study), } \\
(2002)^{(91)} \text {, daily intake } \\
\text { calculated in Hilbig et al. (2004) })^{(26)}\end{array}$} & \multirow{3}{*}{$\begin{array}{l}\text { Calculation over the total food intake } \\
\text { (diet records) of } 3387 \text { children }\end{array}$} & $<1$ year & 0.21 \\
\hline & & $1-7$ years & 0.43 \\
\hline & & $7-19$ years & 0.30 \\
\hline $\begin{array}{l}\text { Wilhelm et al. (RUB Study), } \\
(2002)^{(92)} \text {, daily intake calculated } \\
\text { in Hilbig et al. }(2004)^{(26)}\end{array}$ & $\begin{array}{l}\text { Calculation over the total food intake } \\
\text { (diet records) of } 119 \text { children }\end{array}$ & $1-<7$ years & 0.61 \\
\hline \multirow{4}{*}{$\begin{array}{l}\text { Scientific Committee of the Norwegian } \\
\text { Food Control Authority }(2002)^{(93)}\end{array}$} & \multirow{4}{*}{$\begin{array}{l}\text { Data on consumption of cereal based } \\
\text { baby food and analysed acrylamide } \\
\text { concentrations, no further details available }\end{array}$} & Boys (6 months) & 0.29 \\
\hline & & Girls (6 months) & 0.31 \\
\hline & & Boys (12 months) & 0.33 \\
\hline & & Girls (12 months) & 0.36 \\
\hline \multirow{3}{*}{$\begin{array}{l}\text { European Commission, Health and } \\
\text { Consumer Protection Directorate } \\
\text { (French Food Safety Agency) }_{(2003)^{(94)}}\end{array}$} & \multirow{3}{*}{$\begin{array}{l}\text { National food consumption data and } \\
\text { analysed acrylamide concentrations } \\
\text { presented by SCF; no further details } \\
\text { available }\end{array}$} & $2-14$ years & \\
\hline & & Mean & 1.4 \\
\hline & & 95th percentile & $2 \cdot 9$ \\
\hline
\end{tabular}

BW, body weight; SCF, Scientific Committee on Food.

The first reported data on acrylamide in foods available on the market were developed by the Swedish National Food Administration using liquid chromatography/tandem mass spectroscopy $(\mathrm{LC} / \mathrm{MS} / \mathrm{MS})^{(96)}$. Since then, several analytical procedures have been developed, including LC/MS/MS and GC/MS with different sensitivity, cost, speed and applicability $^{(90)}$.

There are a limited number of studies concerning the daily intake of acrylamide from foodstuffs. In the year 2002, the Swedish National Food Agency showed that certain fried, baked and deep-fried foods and coffee had high concentrations of acrylamide ${ }^{(96)}$. In a Norwegian study, acrylamide exposure from foods and coffee was estimated to be 0.49 and $0.46 \mu \mathrm{g} / \mathrm{kg} \mathrm{BW}$ in males and females, respectively ${ }^{(97)}$. The New Zealand National Nutrition Survey showed that with a typical Western diet, including hot chips (French fries) and potato crisps, the calculated daily intake of acrylamide is $0 \cdot 3 \mu \mathrm{g} / \mathrm{kg} \mathrm{BW}$, which is below the NOAEL ${ }^{(98)}$.

On the other hand, as babies and children are a more sensitive population than adults, their consumption of foods including acrylamide must be limited. The studies calculating the daily intake of acrylamide of children in several European countries are summarised in Table $4^{(11,90,99-103)}$.

The European Union gives high importance to acrylamide contamination in food. After the Commission Recommendation 2007/331/EC, twenty-one member states of the European Union presented the results of acrylamide in several foodstuffs (presented under the titles of 'French fries', 'potato crisps', 'potato products for home cooking', 'bread', 'breakfast cereals', 'biscuits', 'roasted coffee', 'jarred baby foods', 'processed cereal-based baby foods' and 'other products') to the European Food Safety Authority in 2007. There were 2715 results reported for foods sampled in 2007, with a minimum of seventy-six reported for 'processed cereal-based baby foods' and a maximum of 854 reported for 'other products'. The arithmetic mean acrylamide content ranged from $44 \mu \mathrm{g} / \mathrm{kg}$ for 'jarred baby foods' to $628 \mu \mathrm{g} / \mathrm{kg}$ for 'potato crisps', with the equivalent geometric means of 31 and $366 \mu \mathrm{g} / \mathrm{kg}$. The 2007 results

Table 4. Studies on acrylamide contamination in baby foods and infant formulas and estimated daily exposures of acrylamide

\begin{tabular}{|c|c|c|c|}
\hline Study & Food type & Analysis method & Estimated daily exposure \\
\hline Rosén \& Hellenäs (2002) ${ }^{(90)}$ & Canned baby food & LC/MS/MS & $7 \cdot 8 \mu \mathrm{g} / \mathrm{kg}$ \\
\hline Jiao et al. $(2005)^{(99)}$ & Infant powdered milk and baby foods & LC/MS & $\begin{array}{l}\text { Ranging between } 3.01 \\
\text { and } 9.06 \mu \mathrm{g} / \mathrm{kg} \text { for infant } \\
\text { powdered milk and } \\
\text { between } 6.80 \text { and } \\
124.93 \mu \mathrm{g} / \mathrm{kg} \text { for baby } \\
\text { foods }\end{array}$ \\
\hline Şenyuva \& Gökmen $(2005)^{(100)}$ & Baby foods & LC/MS & $149(\mathrm{SD} 14 \cdot 7) \mu \mathrm{g} / \mathrm{kg}$ \\
\hline Fohgelberg et al. $(2005)^{(11)}$ & Canned baby food & LC/MS & $7.8 \mu \mathrm{g} / \mathrm{kg}$ \\
\hline $\begin{array}{l}\text { Scientific and Technological Research } \\
\text { Council of Turkey }(2006)^{(101)}\end{array}$ & Baby biscuits & LC/MS & $150-610 \mu \mathrm{g} / \mathrm{kg}$ \\
\hline $\begin{array}{l}\text { European Food Safety Authority } \\
\text { Scientific Report }(2009)^{(102)}\end{array}$ & Jarred baby foods & LC/MS & $\begin{array}{l}\text { Ranging between } 44 \text { and } \\
628 \mu \mathrm{g} / \mathrm{kg}\end{array}$ \\
\hline $\begin{array}{l}\text { Bundesamt für Verbraucherschutz } \\
\text { und Lebensmittelsicherheit } \\
\text { (Federal Office for the Protection } \\
\text { of the Consumer and Food Safety, } \\
\text { Germany) (2003) })^{(103)}\end{array}$ & $\begin{array}{l}\text { Baby foods (infant formulas and follow-on } \\
\text { formulas, commercial cereal-based food, } \\
\text { commercial menus for infants and young } \\
\text { children, commercial vegetable or fruit } \\
\text { preparations) } \\
\text { Commercial cereal-basedfood } \\
\text { Cakes for infants and young children }\end{array}$ & LC/MS & $\begin{array}{l}\text { Maximum } 131 \mu \mathrm{g} / \mathrm{kg} \\
\text { Mean } 13, \text { maximum } \\
633 \mu \mathrm{g} / \mathrm{kg}\end{array}$ \\
\hline
\end{tabular}

LC/MS/MS, liquid chromatography/tandem mass spectroscopy. 
were compared with results collected by the European Commission Joint Research Centre's Institute for Reference Materials and Measurements in the years 2003 to 2006. There were 9311 results reported for foods sampled in the 4 years; however, there were only eight results reported for the food category 'jarred baby foods' and they were not included in the comparison. The arithmetic mean of acrylamide content ranged from $55 \mu \mathrm{g} / \mathrm{kg}$ for "cerealbased baby foods' to $678 \mu \mathrm{g} / \mathrm{kg}$ for 'potato crisps', with the equivalent geometric means of 35 and $514 \mu \mathrm{g} / \mathrm{kg}$. The highest 95th percentile value was reported for 'potato crisps' at $1718 \mu \mathrm{g} / \mathrm{kg}$ and the highest maximum for 'other products' at $7834 \mu \mathrm{g} / \mathrm{kg}^{(102)}$.

\section{Conclusion}

Infants and children are susceptible towards the effects of several xenobiotics. The knowledge of all factors that affect the formation of glycidamide is important with respect to estimating risk from this known carcinogen. It is known that the metabolism and clearance of drugs are higher in children because of the larger liver:BW ratio and the higher blood flow through the liver compared with those of older adults ${ }^{(104)}$. As the major metabolite of acrylamide, glycidamide, is formed through biotransformation, it is likely that glycidamide can be formed at an higher rate than adults in children. In addition, the detoxification pathway through conjugation with GSH may be less functional due to low levels of GSH in a child's liver. Therefore, it is possible that the toxicity of acrylamide might be higher in children.

Children and adolescents should eat a balanced and assorted diet, which includes plenty of fruit and vegetables but also cereals. Also, parents should moderate their children's consumption of fried and fatty foods. Such a diet would also reduce the risk of high exposures to acrylamide, since acrylamide has not been determined in unheated or boiled foods ${ }^{(105)}$. Acrylamide presumably will also be present in low levels in a nutritionally balanced diet; however, it is in the power of parents to feed their children with more healthy foods. On the other hand, for small children who are merely fed with infant formula and baby food, it is obligatory for governments to take serious measures to monitor contaminants ${ }^{(89)}$.

Taking into account all the knowledge given above, baby food and infant formulas should be routinely tested before use for the detection of acrylamide using improved techniques. Strict law enforcement should be undertaken regarding the detection of all the contaminants in infant formulas and baby foods. Furthermore, producers should be warned by regulatory authorities regarding good manufacturing practices to decrease the levels of contaminants, particularly acrylamide.

\section{Acknowledgements}

The present review was not supported by any funding.

P. E. and T. B. are working as faculty staff in the Department of Toxicology, Hacettepe University Faculty of Pharmacy and prepared this review together with equal contribution to the text.

There are no conflicts of interest.

\section{References}

1. United Nations Treaty Collection (2009) Convention of the Rights of a Child. United Nations Treaty Collection. http://treaties.un.org/Pages/ViewDetails.aspx?src=TREA TY\&mtdsg_no $=\mathrm{IV}-11 \&$ chapter $=4 \&$ lang $=$ en $\quad($ accessed 25 January 2010).

2. Anonymous (2009) Infant formula. http://www.answers. com/topic/infant-formula (accessed 25 January 2010).

3. Nasirpour A, Scher J \& Desobry S (2006) Baby foods: formulations and interactions (a review). Crit Rev Food Sci Nutr 46, 665-681.

4. Joeckel RJ \& Phillips SK (2009) Overview of infant and pediatric formulas. Nutr Clin Pract 24, 356-362.

5. O'Connor NR (2009) Infant formula. Am Fam Physician 79, 565-570.

6. Wharton BA (1989) An approach to setting maxima in infant formulas. J Nutr 119, 1768-1772.

7. Turconi G, Guarcello M, Livieri C, et al. (2004) Evaluation of xenobiotics in human milk and ingestion by the newborn - an epidemiological survey in Lombardy (Northern Italy). Eur J Nutr 43, 191-197.

8. Booker SM (2001) NTP center reports on phthalate concerns. Environ Health Perspect 109, A260-A261.

9. Center for Science in the Public Interest (2003) Petition to establish interim acceptable levels for acrylamide in major food sources, submitted by the Center for Science in the Public Interest, 4 June 2003. http://cspinet.org/new/pdf/ acrylamide_petition.pdf (accessed on 30 April 2010).

10. International Agency for Research on Cancer (1994) Monographs on the Evaluation of Carcinogenic Risks to Humans: Some Industrial Chemicals no. 60. Lyon, France: IARC.

11. Fohgelberg P, Rosén J, Hellenäs KE, et al. (2005) The acrylamide intake via some common baby food for children in Sweden during their first year of life - an improved method for analysis of acrylamide. Food Chem Toxicol $\mathbf{4 3}$, 951-959.

12. Friedman M (2003) Chemistry, biochemistry, and safety of acrylamide. A review. Agric Food Chem 51, 4504-4526.

13. Wenzl T, De La Calle MB \& Anklam E (2003) Analytical methods for the determination of acrylamide in food products: a review. Food Addit Contam 20, 885-902.

14. Miller MJ, Carter DE \& Sipes IG (1982) Pharmacokinetics of acrylamide in Fisher-344 rats. Toxicol Appl Pharmacol 63, 36-44.

15. Viator C \& Muth MK (2004) Acrylamide: the Next Food Safety Issue. Choices; 1st Quarter 2004. http://www. choicesmagazine.org/2004-1/2004-1-03.pdf (accessed 25 January 2010).

16. Choe E \& Min DB (2006) Chemistry and reactions of reactive oxygen species in foods. Crit Rev Food Sci Nutr 46, $1-22$.

17. Schettgen T, Weiss T, Drexler H, et al. (2003) A first approach to estimate the internal exposure to acrylamide in smoking and non-smoking adults from Germany. Int $\mathrm{J} H y g$ Environ Health 206, 9-14.

18. Lantz I, Ternité R, Wilkens J, et al. (2006) Studies on acrylamide levels in roasting, storage and brewing of coffee. Mol Nutr Food Res 50, 1039-1046.

19. Dearfield KL, Douglas GR, Ehling UH, et al. (1995) Acrylamide: a review of its genotoxicity and an assessment of heritable genetic risk. Mutat Res 330, 71-99.

20. Edwards PM (1976) The insensitivity of the developing rat fetus to the toxic effects of acrylamide. Chem Biol Interact 12, 13-18. 
21. Bergmark E, Calleman CJ, He F, et al. (1993) Determination of hemoglobin adducts in humans occupationally exposed to acrylamide. Toxicol Appl Pharmacol 120, $45-54$.

22. Jägerstad M \& Skog K (2005) Genotoxicity of heatprocessed foods. Mutat Res 574, 156-172.

23. Sumner SC, Fennell TR, Moore TA, et al. (1999) Role of cytochrome P450 2E1 in the metabolism of acrylamide and acrylonitrile in mice. Chem Res Toxicol 12, 1110-1116.

24. Dybing E \& Sanner T (2003) Risk assessment of acrylamide in foods. Toxicol Sci 75, 7-15.

25. Carere A (2006) Genotoxicity and carcinogenicity of acrylamide: a critical review. Ann Ist Super Sanita 42, 144-155.

26. Hilbig A, Freidank N, Kersting M, et al. (2004) Estimation of the dietary intake of acrylamide by German infants, children and adolescents as calculated from dietary records and available data on acrylamide levels in food groups. Int $J$ Hyg Environ Health 207, 463-471.

27. Sumner SC, Selvaraj L, Nauhaus SK, et al. (1997) Urinary metabolites from F344 rats and B6C3F1 mice coadministered acrylamide and acrylonitrile for 1 or 5 days. Chem Res Toxicol 10, 1152-1160.

28. Rice JM (2005) The carcinogenicity of acrylamide. Mutat Res 580, 3-20.

29. Hashimoto K \& Tanii H (1985) Mutagenicity of acrylamide and its analogues in Salmonella typhimurium. Mutat Res 158, 129-133.

30. National Toxicology Program (1989) NTP toxicology and carcinogenesis studies of $N$-methylolacrylamide (CAS no. 924-42-5) in $\mathrm{F} 344 / \mathrm{N}$ rats and $\mathrm{B} 6 \mathrm{C} 3 \mathrm{~F} 1$ mice (gavage studies). Natl Toxicol Program Tech Rep Ser 352, 1-204.

31. Russell B, Hunsicker PR, Cacheiro NL, et al. (1991) Induction of specific-locus mutations in male germ cells of the mouse by acrylamide monomer. Mutat Res 262, $101-107$

32. Hoorn AJ, Custer LL, Myhr BC, et al. (1993) Detection of chemical mutagens using Muta Mouse: a transgenic mouse model. Mutagenesis 8, 7-10.

33. Dearfield KL, Abernathy CO, Ottley MS, et al. (1988) Acrylamide: its metabolism, developmental and reproductive effects, genotoxicity, and carcinogenicity. Mutat Res 195, 45-77.

34. Segerbäck D, Calleman CJ, Schroeder JL, et al. (1995) Formation of $\mathrm{N}$-7-(2-carbamoyl-2-hydroxyethyl)guanine in DNA of the mouse and the rat following intraperitoneal administration of $\left[{ }^{14} \mathrm{C}\right]$ acrylamide. Carcinogenesis 16, 1161-1165.

35. Fu PP, Von Tungeln LS, Hammons GJ, et al. (2000) Metabolic activation capacity of neonatal mice in relation to the neonatal mouse tumorigenicity bioassay. Drug Metab Rev 32, 241-266.

36. Gamboa da Costa G, Churchwell MI, Hamilton LP, et al. (2003) DNA adduct formation from acrylamide via conversion to glycidamide in adult and neonatal mice. Chem Res Toxicol 16, 1328-1337.

37. Ma H, Wang W, Yang Y, et al. (2008) Studies on DNA damage and repair induced by acrylamide in cells from mouse various organs (article in Chinese). Wei Sheng Yan Јіи 37, 612-614.

38. Cao J, Liu Y, Jia L, et al. (2008) Curcumin attenuates acrylamide-induced cytotoxicity and genotoxicity in HepG2 cells by ROS scavenging. J Agric Food Chem 56, 12059-12063.

39. Zhang X, Jiang L, Geng C, et al. (2008) Inhibition of acrylamide genotoxicity in human liver-derived HepG2 cells by the antioxidant hydroxytyrosol. Chem Biol Interact 176, 173-178.

40. Baum M, Loeppky RN, Thielen S, et al. (2008) Genotoxicity of glycidamide in comparison to 3- $\mathrm{N}$ nitroso-oxazolidin-2-one. J Agric Food Chem 56, 5989-5993.

41. Wolf T, Niehaus-Rolf C, Banduhn N, et al. (2008) The hen's egg test for micronucleus induction (HET-MN): novel analyses with a series of well-characterized substances support the further evaluation of the test system. Mutat Res 650, 150-164.

42. Recio L, Hobbs C, Caspary W, et al. (2010) Dose-response assessment of four genotoxic chemicals in a combined mouse and rat micronucleus (MN) and Comet assay protocol. J Toxicol Sci 35, 149-162.

43. Mei N, McDaniel LP, Dobrovolsky VN, et al. (2010) The genotoxicity of acrylamide and glycidamide in big blue rats. Toxicol Sci 15, 412-421.

44. National Toxicology Program (2005) NTP-CERHR Monograph on the Potential Human Reproductive and Developmental Effects of Acrylamide. NTP CERHR MON 14, i-III76.

45. Calleman CJ, Stern LG, Bergmark E, et al. (1992) Linear versus nonlinear models for hemoglobin adduct formation by acrylamide and its metabolite glycidamide: implications for risk estimation. Cancer Epidemiol Biomarkers Prev 1, $361-368$

46. Bergmark E, Calleman CJ \& Costa LG (1991) Formation of hemoglobin adducts of acrylamide and its epoxide metabolite glycidamide in the rat. Toxicol Appl Pharmacol 111, 352-363.

47. Höke A (2006) Neuroprotection in the peripheral nervous system: rationale for more effective therapies. Arch Neurol 63, 1681-1685.

48. Murray L (1996) Acrylamide. http://www.inchem.org/ documents/pims/chemical/pim652.htm (accessed 25 January 2010).

49. Cavanagh JB (1982) The pathokinetics of acrylamide intoxication: a reassessment of the problem. Neuropathol Appl Neurobiol 8, 315-336.

50. LoPachin RM, Jones RC, Patterson TA, et al. (2003) Application of proteomics to the study of molecular mechanisms in neurotoxicology. Neurotoxicology 24, $761-775$.

51. LoPachin RM (2004) The changing view of acrylamide neurotoxicity. Neurotoxicology 25, 617-630.

52. LoPachin RM, Ross JF, Reid ML, et al. (2002) Neurological evaluation of toxic axonopathies in rats: acrylamide and 2,5hexanedione. Neurotoxicology 23, 95-110.

53. LoPachin RM \& DeCaprio AP (2005) Protein adduct formation as a molecular mechanism in neurotoxicity. Toxicol Sci 86, 214-225.

54. LoPachin RM \& Gavin T (2008) Acrylamide-induced nerve terminal damage: relevance to neurotoxic and neurodegenerative mechanisms. J Agric Food Chem 56, 5994-6003.

55. Burek JD, Albee RR, Beyer JE, et al. (1980) Subchronic toxicity of acrylamide administered to rats in the drinking water followed by up to 144 days of recovery. J Environ Pathol Toxicol 4, 157-182.

56. Chapin RE, Fail PA, George JD, et al. (1995) The reproductive and neural toxicities of acrylamide and three analogues in Swiss mice, evaluated using the continuous breeding protocol. Fundam Appl Toxicol 27, 9-24.

57. Ghanayem BI, Bai R, Kissling GE, et al. (2010) Dietinduced obesity in male mice is associated with reduced fertility and potentiation of acrylamide-induced reproductive toxicity. Biol Reprod 82, 96-104. 
58. Zenick H, Hope E \& Smith MK (1986) Reproductive toxicity associated with acrylamide treatment in male and female rats. J Toxicol Environ Health 17, 457-472.

59. Sublet VH, Zenick H \& Smith MK (1989) Factors associated with reduced fertility and implantation rates in females mated to acrylamide-treated rats. Toxicology $\mathbf{5 5}$, $53-67$.

60. Wise LD, Gordon LR, Soper KA, et al. (1995) Developmental neurotoxicity evaluation of acrylamide in Sprague-Dawley rats. Neurotoxicol Teratol 17, 189-198.

61. Field EA, Price CJ, Sleet RB, et al. (1990) Developmental toxicity evaluation of acrylamide in rats and mice. Fundam Appl Toxicol 14, 502-512.

62. Tyl RW, Marr MC, Myers CB, et al. (2000) Relationship between acrylamide reproductive and neurotoxicity in male rats. Reprod Toxicol 14, 147-157.

63. Sakamoto J \& Hashimoto K (1986) Reproductive toxicity of acrylamide and related compounds in mice - effects on fertility and sperm morphology. Arch Toxicol 59, 201-205.

64. Costa LG, Deng H, Gregotti C, et al. (1992) Comparative studies on the neuro- and reproductive toxicity of acrylamide and its epoxide metabolite glycidamide in the rat. Neurotoxicology 13, 219-224.

65. Miller MG, Mulholland DJ \& Vogl AW (1999) Rat testis motor proteins associated with spermatid translocation (dynein) and spermatid flagella (kinesin-II). Biol Reprod 60, 1047-1056.

66. Tyl RW \& Friedman MA (2003) Effects of acrylamide on rodent reproductive performance. Reprod Toxicol 17, 1-13.

67. Friedman MA, Tyl RW, Marr MC, et al. (1999) Effects of lactational administration of acrylamide on rat dams and offspring. Reprod Toxicol 13, 511-520.

68. Shiraishi Y (1978) Chromosome aberrations induced by monomeric acrylamide in bone marrow and germ cells of mice. Mutat Res 57, 313-324.

69. Adler ID, Zouh R \& Schmid E (1993) Perturbation of cell division by acrylamide in vitro and in vivo. Mutat Res 301, 249-254.

70. Sickles DW, Brady ST, Testino A, et al. (1996) Direct effect of the neurotoxicant acrylamide on kinesin-based microtubule motility. J Neurosci Res 46, 7-17.

71. Sega GA, Alcota RP, Tancongco CP, et al. (1989) Acrylamide binding to the DNA and protamine of spermiogenic stages in the mouse and its relationship to genetic damage. Mutat Res 216, 221-230.

72. Sega GA (1991) Adducts in sperm protamine and DNA vs. mutation frequency. Prog Clin Biol Res 372, 521-530.

73. Lähdetie J, Suutari A \& Sjöblom T (1994) The spermatid micronucleus test with the dissection technique detects the germ cell mutagenicity of acrylamide in rat meiotic cells. Mutat Res 309, 255-262.

74. Manson J, Brabec MJ, Buelke-Sam J, et al. (2005) NTPCERHR expert panel report on the reproductive and developmental toxicity of acrylamide. Birth Defects Res $B$ Dev Reprod Toxicol 74, 17-113.

75. World Health Organization (2010) Food Safety. Questions related to Cancer. http://www.who.int/foodsafety/ publications/chem/acrylamide_faqs/en/index $1 . h t m l$ (accessed 25 January 2010).

76. Konings EJ, Baars AJ, van Klaveren JD, et al. (2003) Acrylamide exposure from foods of the Dutch population and an assessment of the consequent risks. Food Chem Toxicol 41, 1569-1579.

77. World Health Organization (2002) Health implications of acrylamide in food. Joint FAO/WHO consultation, Geneva, Switzerland, 25-27 June 2002. http://www.who.int/ foodsafety/publications/chem/acrylamide_june2002/en/ index.html (accessed 25 January 2010).

78. McCollister DD, Oyen F \& Rowe VK (1964) Toxicology of acrylamide. Toxicol Appl Pharmacol 103, 172-181.

79. Kuperman AS (1958) Effects of acrylamide on the central nervous system of the cat. Pharmacol Exp Ther 123, 180-192.

80. Thomann P, Koella WP, Krinke G, et al. (1974) The assessment of peripheral neurotoxicity in dogs: comparative studies with acrylamide and clioquinol. Agent Actions 4, 47-53.

81. Hopkins A (1970) The effect of acrylamide on the peripheral nervous system of the baboon. J Neurol Neurosurg Psychiatry 33, 805-816.

82. Fullerton PM \& Barnes JM (1966) Peripheral neuropathy in rats produced by acrylamide. Br J Ind Med 23, 210-221.

83. Spencer PS, Sabri MI, Schaumburg HH, et al. (1979) Does a defect in energy metabolism in the nerve fiber underlie axonal degeneration in polyneuropathies? Ann Neurol 5, 501-507.

84. Johnson KA, Gorzinski SJ, Bodner KM, et al. (1986) Chronic toxicity and oncogenicity study on acrylamide incorporated in the drinking water of Fischer 344 rats. Toxicol Appl Pharmacol 85, 154-168.

85. Friedman MA, Dulak LH \& Stedham MA (1995) A lifetime oncogenicity study in rats with acrylamide. Fundam Appl Toxicol 27, 95-105.

86. Parzefall W (2008) Review on the toxicity of dietary acrylamide. Food Chem Toxicol 46, 1360-1364.

87. Shipp A, Lawrence G, Gentry R, et al. (2006) Acrylamide: review of toxicity data and dose-response analyses for cancer and noncancer effects. Crit Rev Toxicol 36, 481-608.

88. Exon JH (2006) A review of the toxicology of acrylamide. J Toxicol Environ Health B Crit Rev 9, 397-412.

89. World Health Organization (2002) FAO/WHO Consultation Report on the Health Implications of Acrylamide in Food, Summary Report. Geneva. 25-27 June 2002. Geneva: WHO.

90. Rosén J \& Hellenäs KE (2002) Analysis of acrylamide in cooked foods by liquid chromatography tandem mass spectrometry. Analyst 127, 880-882.

91. Alexy U, Sichert-Hellert W, Kersting M, et al. (2001) The foods most consumed by German children and adolescents: results of the DONALD Study. Ann Nutr Metab 45, $128-134$.

92. Wilhelm M, Schrey P, Wittsiepe J, et al. (2002) Dietary intake of persistent organic pollutants (POPs) by German children using duplicate portion sampling. Int $J$ Hyg Environ Health 204, 359-362.

93. Scientific Committee of the Norwegian Food Control Authority (2002) Risk assessment of acrylamide intake from cereal-based baby foods. Report from the Scientific Committee of the Norwegian Food Control Authority. http://www.snt.no/nytt/tema/Akrylamid/RA_baby_food.pdf (accessed 30 April 2010).

94. European Commission, Health and Consumer Protection Directorate (2003) Acrylamide. EU Summary of Activites. http://europa.eu.int/comm/food/fs/sfp/fcr/acrylamide/ study_area2.pdf (accessed 30 April 2010).

95. Friedman M \& Levin CE (2008) Review of methods for the reduction of dietary content and toxicity of acrylamide. J Agric Food Chem 56, 6113-6140.

96. Swedish National Food Agency (2002) Press Conference. Uppsala, 21 April 2002. http://www.slv.se/upload/nfa/ documents/about_us/org_nfa.pdf 
97. Norwegian Food Agency (2002) Risk assessment of acrylamide intake from foods with emphasis on cancer risk. http://www.snt.no (accessed 25 January 2010).

98. Food Standards Australia and New Zealand (2009) Acrylamide in food. http://www.foodstandards.gov.au/ newsroom/factsheets/factsheets2009/ acrylamideinfoodfebr4211.cfm (accessed 25 January 2010).

99. Jiao J, Zhang Y, Ren Y, et al. (2005) Development of a quantitative method for determination of acrylamide in infant powdered milk and baby foods in jars using isotope dilution liquid chromatography/electrospray ionization tandem mass spectrometry. J Chromatogr A 1099, 198-202.

100. Șenyuva HZ \& Gökmen V (2005) Survey of acrylamide in Turkish foods by an in-house validated LC-MS method. Food Addit Contam 22, 204-209.

101. Anonymous (2006) Estimation of the Scientific and Technological Research Council of Turkey for
Acrylamide. http://www.kansernotlari.blogspot.com/ 2006_11_01_archive.html (accessed 25 January 2010).

102. European Food Safety Authority (2009) Results on the monitoring of acrylamide levels in food. In The EFSA Scientific Report, no. 285, pp. 1-26. Parma, Italy: EFSA.

103. Bundesamt für Verbraucherschutz und Lebensmittelsicherheit (2003) Acrylamidgehalte in Lebensmitteln. Daten vom 15.01. bis 25.03.2003 (Acrylamide levels in food. Data from 15 January to 25 March 2003). http://www.bvl.bund.de/dl/ Acrylamid25.pdf (accessed 30 April 2010).

104. Greim H \& Snyder R (editors) (2008) Toxicology and Risk Assessment. A Comprehensive Introduction. Chichester, West Sussex: John Wiley \& Sons.

105. Tareke E, Rydberg P, Karlsson P, et al. (2002) Analysis of acrylamide, a carcinogen formed in heated foodstuffs. J Agric Food Chem 50, 4998-5006. 